\title{
Slum upgrading and placemaking: improving informal settlements and creating places
}

Natalia Meléndez Fuentes natmfu@gmail.com

Universidad Pontificia Comillas. Madrid. Espanha.

\section{Heike Clara Pintor Pirzkall} hcpintor@comillas.edu

Universidad Pontificia Comillas. Madrid. Espanha.

\begin{abstract}
Since the creation of UN-Habitat in 1978, development agendas have shown an increased global focus in cities and urban challenges. Fast-growing urbanization rates the world over, urban challenges, and in particular slums, critically hinder human progress. Despite the international recognition, conventional approaches to the slum question fail to accomplish solid results. Evidence has it that Latin America has become the world's signpost in integral, inclusive urban development. The few comprehensive, yet crucial, slum upgrading programs being implemented in the region attest to that. We see the potential in this region to lead to a better future for slum upgrading-ergo, for human development. For that purpose, we have selected ten representative Latin American slum upgrading programs to help us illustrate our proposed methodology for achieving more comprehensive and sustainable results in slum upgrading practices.
\end{abstract}

KEYWORDS: urban development, human development, Latin America, slum upgrading, social urbanism, placemaking. 


\section{INTRODUCTION}

The slum question is the ultimate example of urban informality. The preservation of slums as we know them, imposes an impasse on urban--ergo, human-development. The right to housing has only been recognized since 1948, in the Universal Declaration of Human Rights. Since then, other international and national documents ${ }^{1}$ have aspired to protect the most vulnerable social echelons at the urban level. But the traditional city management model has not changed, despite these and other efforts to include the poorest (Balbim, 2016: 81). This is so because, to a far greater extent than other social products (as education, health care or security), housing is a market product. Housing is composed by the interweaving of state activities, the market's, and social needs, and as such, it is the welfare sector with most market interests vested (Esping-Andersen, 1990: 21).

The immediate reaction vis-à-vis the informal is of neglect. The slum question has only recently become a problem for the authorities. For long, urban informality was an economic engine the formal city tolerated, one that was part of an economic growth that made informal settlers even more vulnerable (Balbim, 2016: 185). It became a problem in the 1800 s, the era of urban beautification. Haussman turned Paris into the imperial city par excellance, and other cities the world over transformed to replicate Paris. Informal, irregular settlements had no place in such beautiful, artificial projects. Slums were cleared, ignoring that they were an outcome of the system and the forces driving that system remained unchanged (Arimah, 2010: 30).

Experience shows that slum clearance is not a solution to the proliferation of slums: after clearance, the informal re-emerges somewhere else. Slum eradication focuses on the symptoms, rather than on the causes of informal settling, and it usually takes place as a result of powerful economic interests for developing profitable formal structures in the area. Another orientation of dealing with urban informality also inclined to obey economic effectiveness is resettlement. Past and present housing policies have entailed the massive production of low-cost housing units for the later relocation of informal settlers (Balbim, 2016: 185). This practice entails the dismembering of communities and their social capital, deeply relegating informal settlers to what is more convenient for other, more powerful, humans.. Slum residents depend on employment in the vicinity of their dwellings, where they have also already established social networks with more affluent neighbors that help them cope with their poverty. Moreover, except rare examples of successful resettlement programs-like that of squatters from Brasilia to Samambaia-, the plots provided in the new locations tend to be extremely insufficient, lacking adequate infrastructure and services, and distant from workplaces and city centers (Arimah, 2010: 3). Nonetheless, in some particular instances resettlement is imperative due to the risk locations of the squatting. When that is the case, there is a need to implement adaptation programs and mitigation of psycho-social impacts (TECHO, 2015: 137).

Urban informality did not become an object of analysis as a field of action until the dominant critiques of modernism in the 1960s and early 1970s, with the works of John Turner, Charles Abrams, William Manguin, and of different members of

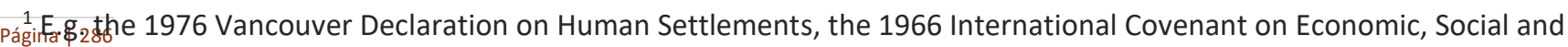
Cultural Rights, the 2005 World Charter for the Right to the City, or the 2007 Santiago Declaration of the Ibero-American States. 
Team X (Hernández et al., 2010: 167). These authors mainly attacked previous treatment of the urban, and advocated for doing away with eradication and resettlement practices when dealing with the slum question. Hence, the underlying idea is that, to overcome urban faults, the informal need to be rethought. In order to rethink the informal, one must focus on identifying its root causes. Informality rethought, the slum question is taken seriously. As mentioned, these times have an urban character where cities accommodate the majority of the world's population and where informality is ever-increasing. To this day, there is an astounding lack of attention to science and research in urbanism among policymakers. By taking the slum question seriously, cleavages between theory and practice, policymakers and (all) stakeholders, north and south, are bridged. When all elements transforming urban informality act in unison in providing capabilities to the urban poor, "architecture returns to its ancestral social meaning of responding and expressing everyday needs through the vital rescuing of lost human dignity" (Hernández et al., 2010: 175).

The leading figure in the theorization of the rethinking of informality was French sociologist, Henri Lefebvre. He elaborated on a seminal urban and philosophical concept: the 'right to the city'. Lefebvre, establishes that the city historically constructed is no longer lived nor understood practically, for there is another way unfulfilled in our cities. Contrary to present practices, such way requires for urban society to be an oeuvre and not a product. He calls for a new humanism to be attained by means of a new life in the city. Until generalized segregation disappears, his 'right to the city' cannot be achieved, as this concept gathers the interests of all those who inhabit (Lefrebvre, 1996: 148-158). Thus, citizens can no longer be labeled by their family names or places of residence. Rather, they should be defined by their belonging to different social networks in family, profession and habitat. To build the 'right to the city', Lefebvre provides a crucial formula for social citizenship: a new Rousseauian contract between state and citizens to reduce the gaps between them and between different peoples within a city, the state an enabler of links between communities; a provider of encompassing rights; and a setter of obligations towards a pluralistic society (Ibid.: 208). Then, the central idea to Lefebvre's postulates is that the right to the city ensues "the capacity to change ourselves by changing the city" (Harvey, 1973: 315). All citizens-formal and informal—would thus be able to fully enjoy urban life: benefiting from all its services and advantages (the right to habitation), and taking direct part in city management (the right to participation). His works press for the urban to raise to its real nature, which is first and foremost human (Lefebvre, 1996: 208).

Rethinking informality and satisfying the 'right to the city' aim for true democracy to be realized. If that is the case, further deliberation is required: what is then the role that both urbanism and architecture must play in/for society? The answer is found in a less-known book of acclaimed architect Frank Lloyd Wright, An Organic Architecture: The Architecture of Democracy. There, he establishes that architecture "ought in one sense or another to be like nature, responsive to nature or at one with nature" (Wright, 1939: 12) and that, "it must be true to time, place, development, environment and purpose (Ibid.: 17). In this sense, the sciences of urbanity need to be performative. When citizens are placed at the epicenter of city planning and management, these fields acquire the power to stimulate a series of social practices. Always along with nature, these sciences assist in delineating the contours of a community. And by reshaping their role in 
society, they can negotiate the inclusion of informality into the city and, thus, better the lives in the informal (Hernández et al., 2010: 130).

Slum upgrading stands thus as the ultimate practice condensing the promotion of the 'right to the city', the democratic and developmental power of both architecture and urbanism, and Amartya Sen's capacity-building approach. Since informality is a reality of contemporary cities, and eradication and resettlement strategies have proven detrimental, the smart way forward is slum upgrading. Complete development cannot avoid any parts of a whole. If massive numbers of-urban and rural-peoples are not given the opportunities to grow to their full potential, then a big share of the global human capital is impeded from contributing to human development.

According to urban theory, slum improvement must solve the immediate physical needs of the poor and empower communities, without disregarding the worthy existing physical and social community assets. It also helps incrementally in the improvement of the greater city, because, as a living entity, when an area is changed, the whole city is impacted (Irazábal, 2009: 23). Moreover, slum upgrading makes highly visible and large differences in the quality of life of urban informal settlers. For instance, unhygienic conditions leading to water-borne diseases are dealt with (World Bank, 1999: 3). Satisfaction with one's life is also incremented, as are safety and perceptions of security. In addition to the foregoing, improvement of city infrastructure attracts more investment, which in turn boosts economic growth. What is more, slum upgrading contributes to a healthy growth, as it supports a self-sufficient improvement, once basic needs are met: prosperity becomes more sustainable, community-building is fostered, and participation and creativity are enhanced (Max-Neef et al., 2010: 38).

Yet, slum upgrading experts, Jeff Ruster and Ivo Imparato, aptly point out that upgrading strategies should go beyond physical improvements to create more integrated emphatic societies: through a broad transformation of relationships within communities, between informal communities and the formal citizenry, and between communities and authorities. Hence, slum upgrading must meticulously heed the particular urban, social, political, cultural and economic contexts (Ruster \& Imparato, 2003: 87). Since the declaration of the Millennium Development Goals (MDGs), many slum upgrading programs have been launched. Yet they failed to transcend physical improvements or, in importing international upgrading models, did not consider the particularities of the site (Irazábal, 2009: 108). International best practices on slum upgrading, which do follow Ruster \& Imparato's ideas, illustrate that rethinking informality is an effective instrument for positive change. In a global context, Latin America is a good testimony of it. A fascinating case-study for slum upgrading, the region hosts most best practices in the field. This new wave of more inclusive slum upgrading is still confined in the region because of the many economic interests vested in perpetuating urban informality, the lack of direct communication between governments and urban experts, and the preference for shorter interventions with more immediate results. Hence, in spite of the larger part of projects still falling short of addressing socio-spatial equity concerns (Ibid.: 24), relevant measures are being taken towards fulfilling Lefebvre's 'right to the city' in Latin America. 


\subsection{Renewing the right to the city: placemaking in latin america}

This article, in developing its own body of theory, urges for a renewal of the Lefebvrian right. The concept should be reinvigorated to specifically and only target the slum question, due to the urgency thereof and, so far, the many inadequate responses to it. Social, economic and physical problems in slum areas and within their larger city-context should be grasped and integrated into city planning. The 'renewed right to the city', becomes an imperative: it cannot be attained if part of the population are not conferred equitable opportunities, and it ought to be attained. State and citizenry alike, should stop lenient tendencies towards the presence of unsanitary slum areas; and cease stigmatization, stereotyping, and undervaluation of the informal. Such 'renewed right to the city', strives for much more far-reaching slum upgrading practices than those in place, urging slum upgrading to turn into a truly comprehensive transformation, by bringing all the brilliance of Lefebvre's postulates to the forefront of slum upgrading.

Echoing Lefebvre's postulates, architects Lynda H. Schneekloth and Robert G. Shibley, defined the concept of 'placemaking' as, "the way in which all of us as human beings transform the places in which we find ourselves into places in which we live" (Schneekloth \& Shibley, 1995: 1). When applied to the context of squatter settlements, the concept of 'placemaking' unveils a whole new dimension for slum upgrading; one that gives access to the emotional and the psychological of these sites. City development has also resulted in the dehumanization of informal settlements. The placemaking approach allows to materialize the life of these settlements in the collective imagination of outsiders. When the Lefebvrian right and placemaking are fully applied to slum upgrading, settlements stop being bypassed/no-go, stigmatized city areas to become places of meaning. As slums acquire human meaning, they are begun to be understood as spatial consequences of complex social processes. In turn, this sensitizes the approach to slum upgrading: now it does not only upgrade, it also acknowledges and enhances the good there found. Borrowing from the human geography aphorism, "as people construct places, places construct people" (Holloway \& Hubbard, 2001: 7), slum upgrading should be conceived and planned "to form a new possibility by means of interaction between the symbolic, the imaginary and the real" (Hernández et al., 2010: 223). In this manner, slum upgrading turns into an enabler for virtuous reciprocity: spaces are improved and enhanced to better residents' lives, and, likewise, fostered coexistence upgrades spaces by adding valuable meanings. As a result, slum upgrading transcends the urban to address all anthropological needs; it becomes a practice that incorporates a set of indispensable elements to satisfy the basic needs that all humans require (Max-Neef et al. 2010: 26).

As previously pointed out, the Latin American countries have been setting new and relevant benchmarks in the slum upgrading field (Irazábal, 2009: 117). By applying the theoretical concepts previously analyzed and by carefully examining best practices of slum upgrading in the region, we have identified a series of necessary elements that must be taken into account in slum upgrading practices. This set of elements has been represented as a pyramid of upgrading needsMeléndez's Pyramid ${ }^{2}--($ See image below), inspired by the Maslow's Hierarchy of Needs. As shown, by covering Max-Neef's fundamental human needs, slum

${ }^{2}$ Having all equal importance for their own purposes, the distribution only denotes logic order in implementation not hierarchy. 
upgrading eventually leads to placemaking. These indispensable elements allow for the 'right to the city' to be renewed and for placemaking to be satisfied. For putting theory into practice, ten case-studies of slum upgrading in Latin America will be further on analyzed to explain the weight of each element and how it can be best achieved.

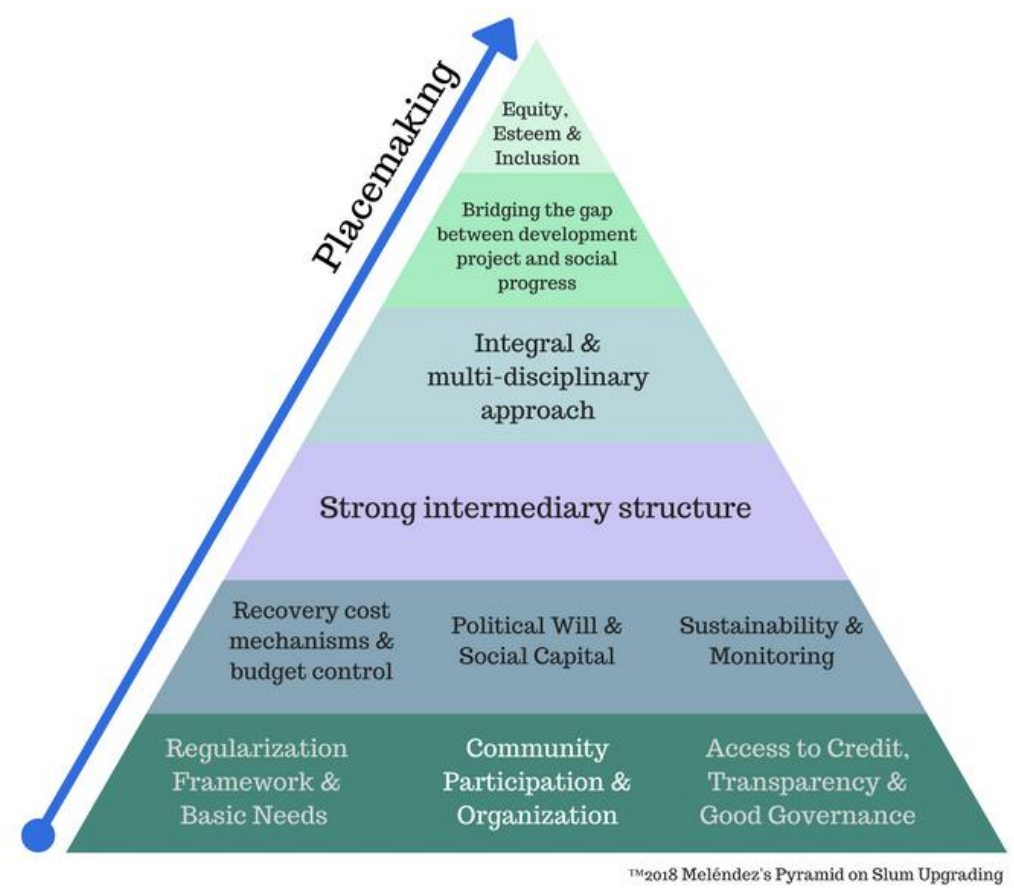

\section{BACKGROUND: BIRTH AND LIFE OF THE LATIN AMERICAN SLUM}

The Latin American region is the world's most urbanized, with almost $80 \%$ of its population living in cities and high levels of informality and slums (Magalhães, 2016: 2). This mainly results from the rapid urbanization of the region during the 20th century, outcome of the increased manufacturing industries that greatly diminished economic reliance on agriculture. The industrialization era heightened rural-urban migration flows, and weak authorities were unable to provide sufficient land, housing services and infrastructure to new residents. Invasion of the periphery was convenient to both invaders and industrial interests: it provided dwelling close to economic opportunities to the former, and adjacent cheap labor to the latter. Hence, forced by market forces and necessity, the newcomers built their self-help homes on the fringes of the Latin American cities (Irazábal, 2009: 78).

Latin American housing policies (which tend not to include slum upgrading practices), all things considered, have not addressed the underlying socio-political elements behind urban informality. This is reflected in the fact that, as of 2014, $23.5 \%$ of the region's population lived in slums (UN Data 2014). In view of this, the region is now slowly incorporating a more integrated and comprehensive approach to slum upgrading, with some landmark examples from previous times (Irazábal, 2009: 104). Still small-scale notwithstanding, these changes are very relevant. The most significant of these has been the shift from upgrading as process that was 
technical, expert and official data driven, and detached from slum dwellers' opinions to one that is more concerned with combining housing solutions, social development, and the creation of inclusive cities (Calderón Arcilla, 2008: 65). A big contribution to ameliorating slum upgrading has been decentralization. By means of it, local governments have acquired planning, fiscal and administrative leverage. Being closer to the informal settlement in question, and now better equipped, municipalities have turned into key players in the upgrading field. Latin America has thus emerged as a leader in the creation of a socially responsible slum upgrading, with Brazil and Colombia leading the way (Magalhães, 2016: 107).

Nonetheless, a plethora of challenges and questions still remain, and older planning styles persist in most cities. Nearly all countries in the region have not carried out a comprehensive reform plan to ameliorate their national housing systems integrally (Calderón Arcilla, 2008: 64-65). This ensues a trap of toxic oblivion: states believe to be taking measures to get better, but, instead, their efforts are running into the sand inasmuch as they remain superficial and sectoral. Because of this, know-how extrapolated to urban development is socially shallow as well. For instance, there is a shortage of funding, technical assistance, coherent national planning, and administrative capacity-building. Obsolete provisions of legal urban orders frustrate urban reform and promote predatory land and speculation practices (Fernandes, 2007: 203). The region also lacks proper information systems to support the interventions at every stage.

For its part, targeting of the lowest-income quintiles still remains a challenge (Magalhães, 2016: 108). The launch of slum upgrading programs is usually marked by the existence of a prior relationship between the government and the slum community-often mediated by clientelism. As a result, slum upgrading tends to reach those who are more convenient to be assisted and not necessarily whomever is in most need (Álvarez Rivadulla, 2014: 6). Product of speculative land markets, clientelism-based political systems, elitist urban planning practices and exclusionary legal regimes, and informal peri-urbanity are today the main socioeconomic ways to produce urban space in Latin America (Fernandes, 2007: 203). The housing deficit in the region is above $30 \%$; that is, $32 \%$ in terms of qualitative housing deficit and 37\% as for quantitative housing deficit (Magalhães, 2016: 4). However, a quantitative housing deficit does not imply homelessness. Most people in the region do have homes ${ }^{3}$, even if they are not provided by the formal market, are overcrowded and/or poorly-serviced.

Turning to the positive new wave of slum upgrading in the region, it goes back to the 1980s Brazilian and Colombian pathways in reforming legal systems for urban development ${ }^{4}$. Since then, slum upgrading has been influenced by the rhetoric of the 'right to the city' to some extent, with participatory budgeting and good governance really making urban progress (Ibid.: 5). In a few cases, the traditional model of planning has gradually evolved into a more collaborative and local planning strategy, including the communities' opinions and desires (Irazábal, 2009: 23). Programs have been designed to redistribute wealth and make the land market more accessible (Magalhães, 2016: 5). Switching the focus from quantity to quality, some recent programs have introduced social support to promote

\footnotetext{
Páginanh 2 y $0.6 \%$ of Latin Americans are homeless (Magalhães, 2016: 114).

${ }^{4}$ As mentioned in a previous section, Colombia and Brazil materialized the 'right to the city' in legal terms with the approval of Law no. 388/1997 (Colombia), and Law No.10.257/2001 (Brazil) —aka. City Statute-.
} 
capacity building and integration. Emphasis has been placed on improving public spaces-especially green areas-as a means of tackling the 'ghetto image' of slums and of increasing squatters' bond with their cities (Hernández et al., 2010: 164). The aesthetic element of this new wave also finds explanation in attracting investment on the city, thus bolstering national economies.

All the improvements notwithstanding, this new wave in slum upgrading is still very limited in scope. The best, most consistent practices are concentrated in a few cities $^{5}$, with the rest of remarkable practices erratically scattered across the region. However, most of these programs are also territorially confined at a local level and, focused on upgrading a specific neighborhood, they rarely generate significant synergies at the city level (Magalhães, 2016: 108). To reverse that, governments need to support these programs at the national level through legal orders and measures that prevent future informality (e.g. diversifying local economies to generate jobs). The underlying explanation for this is that a policy of neglect towards slums still prevails by reason of the interests vested-by influential stakeholders-in perpetuating present socio-economic dynamics. Latin America also requires further environmental commitment in slum upgrading, as green policies are not integrated in planning, nor exists an attempt to raise environmental awareness (Ezquiaga, 2015: 9). Thereby, this new wave needs to devise a strategic approach to slum upgrading that enhances connectivity, mobility, urban integration, social cohesion and access to affordable land (Magalhães, 2016: 9). As long as settler's fundamental basic needs are not satisfied, urban development will not be whole.

As aforementioned, this article has conducted extensive research on the topic in order to identify how the fundamental human needs can be best satisfied through slum upgrading and placemaking. To that end the referred pyramid of urban needs was conceived. The elements that constitute the pyramid have been identified in slum upgrading projects appertaining to this new slum upgrading wave in Latin America. The following section will attempt to exemplify each of the elements by the experience attained in a particular program, in an effort to convey the indispensability of that element in question. This research stands thus as a modest endeavor to infuse the relevance of acknowledging all of Max-Neef's fundamental basic needs in slum upgrading practices.

\section{ANALYSIS AND DISCUSSION}

The present study proposes a set of indispensable elements that slum upgrading must include in order to fulfill the fundamental human needs (Max-Neef et al. 2010: 26). This is not an attempt to provide a one-size-fits-all solution. On the contrary, we recognize the importance of a bottom-up approach, which permits meeting and prioritizing the specific needs of informal settlers. The future slum upgrading paradigm should aim for satisfying all human needs by means of a gradual, integrated and multi-disciplinary rehabilitation of precarious slum areas. The intervention shall consist of strong economic and sociocultural development strategies, with a special emphasis on social capital, equity, esteem, and inclusion. The paradigm must also advocate for close cooperation among the different

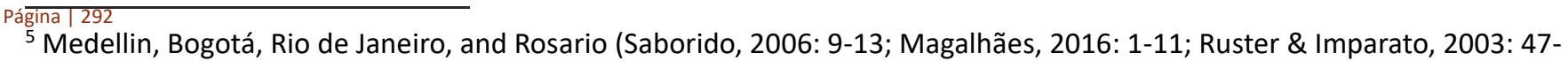
95).
} 
stakeholders, specially allowing for the participation of the community at all stages. Upgrading programs should be further supported by regularization tools, political will, good governance and sufficient credit. The presence of a strong intermediary structure is envisaged to facilitate full transparency, as well as to streamline recovery-cost, budget-control and monitoring systems. All these elements together enable to bridge the gap between a development project and social progress, which is a guarantee of sustainability. The formulation of the Meléndez's Pyramid is therefore an association of the potential, the ideal, and the rational regarding slum upgrading. Its ten blocs, each embodied by a slum upgrading program in Latin America, are detailed hereunder.

\subsection{Regularization framework and coverage of basic needs: Pró-Favela Program (Brazil)}

In 1983, Belo Horizonte, Brazil became the first municipality in the world to adopt a legal instrument for the regularization of informal settlements (Pró-Favela Law). This had been the result of well-organized social movements and lobbying at the end of the military regime. The PRÓ-FAVELA Program fosters the urban and legal regularization of favelas through their inclusion in the city. Such action positively reverberates in the community in the form of basic services and infrastructure, access to politics, and the legalization of land tenure (Fernandes \& Pereira, 2010: 171-199). The Pró-Favela Program is revolutionary for two reasons. First, it pioneered in recognizing the relevance of regularization, acknowledging its beneficial outgrowths. And second, it delivers an ideal methodology to enforce it. Most squatters live without any form of secure tenure, permanently threatened by eviction. Thus, for slum upgrading to be sustainable, regularization is essential. In order to properly plan the upgrading of slums; legal, regulatory and procedural bottlenecks imposing unrealistic requirements for land use must be eliminated (Ruster \& Imparato, 2003: 227).

In order to properly regularize slums, the Pró-favela Program introduced the concept, 'zones of special social interest' (ZEIS). This tool sets the framework for certain areas to be assisted and included into the formal city. Given the physical characteristics of favelas, it was impossible to adhere these areas to existing, formal codes, impeding their upgrading and perpetuating their precariousness. Hence, the ZEIS allow for the temporary suspension and relaxation of relevant laws to ease the upgrading and land regularization processes. Thus, when an area is recognized as ZEIS, the authorities are obliged to regularize and, by extension, to assist it (Fernandes \& Pereira, 2010: 171-199).

Regularization goes hand in hand with the provision of basic services. Together, these two elements cover for many of the settler's anthropological needs, mainly physical, economic, and, thus, political. Basic urban services and infrastructure include potable water access, sanitation, sewage systems, electricity and street lighting, storm drainage, garbage collection, and street and road pavement. Upgrading must also encompass community services such as playgrounds, schools, markets, daycare centers, and clinics. In order to ensure sustainability, all these actions must be tailored to the location and community. The Pró-Favela Program conducted this process through the use of Geographic Information Systems (GIS). These systems engage in spatial and socio-economic data collection. Ideally, when applied to slum upgrading projects, communities 
participate in data collection adding their own perceptions. Some of the variables are: proxies for sanitation, crowding, income and access to water, proportion of households without a bathroom, or average income of heads of household per month (Hacker et al., 2013: 10). Very valuable to the amelioration of basic services provision, GIS inform policy making, creating an overall vision of the real situation and problems.

Through the Pró-Favela Law and Program to guide the improvement of favelas, Belo Horizonte successfully included the 'right to the city' into its planning process. The impact of the program (e.g. by reaching 120,000 residents in 5 slum areas) proves the utmost importance that slum upgrading must attach to regularization and basic services provision. However, the Pró-Favela Program shows that having institutional support and the proper tools to affect change does not suffice. Despite the Pró-Favela's efforts, $13 \%$ of Belo Horizonte's population (307,038 people) still live in irregular slum areas (Carvalho, 2013: 3). When squatting levels are of such magnitudes, upgrading programs need to become more 'market compatible'-i.e., more acceptable to economic forces-, and to strengthen its legal base so as to meet political and bureaucratic challenges. Given these circumstances, regularization and basic services provision constitute an indispensable, solid understructure to the upgrading of slums.

\subsection{Community participation and organization: Villa El Salvador (Peru)}

Villa El Salvador (henceforth VES), located in Southern Lima, is one of the biggest squatter settlements in Peru and an extraordinary example of community empowerment. It was founded in 1971 as a government-led housing scheme to accommodate 4,000 squatter families living in central Lima. Land was allocated in the desert (26 km away from the city center) with no services or infrastructure whatsoever. Nevertheless, the Integral Development Plan (1984-ongoing)-a partnership between the government and the local community-based organizations (henceforth $\mathrm{CBOs}$ ) - has allowed the slum area to enjoy basic services, infrastructure, housing, and formal inclusion into the city of Lima. The VES Plan epitomizes the power and relevance of community participation and organization in slum upgrading programs. Some 40 years later, and after a long constant process of self-upgrading, VES is now home to 350,000 people who do not suffer from lack of basic services and infrastructure, or of shortness of political voice (Bartesaghi Koc, 2014: 1-7).

Through community participation and organization, settlers influence resource allocation, planning, design, implementation, monitoring and maintenance policies. That is, dwellers are present at all upgrading stages, with more or less intensity depending on their needs, interests and skills. As it is the case in the VES Plan, these elements must be complemented by a self-help and participatory budgeting model, in which the funding entity acts as a provider and a technical advisor, with most of the upgrading being performed by the community itself. This action offered the opportunity to change the dynamics between the community and the authorities: paternalism was overcome and interaction on a more equal foot was fostered (Ruster \& Imparato, 2003: 9). Also, devoid of the influence of momentary political climates, VES' bottom-up approach ensured sustainable and positive city changes. 
In the case of VES, there is a strong and highly-organized CBO (the SelfManaged Urban Community of Villa El Salvador, or CUAVES) that knows the workings of political and governmental mechanisms. In this manner, this CBO can directly communicate with the authorities, exerting significant pressure (Ruster \& Imparato, 2003: 431-433). The result of this acquired political voice is that people are capacitated to make the necessary demands to improve their quality of life (e.g. funds and technical advice for building infrastructure) (Stein, 2001: 33). Given the complexity present in VES-which is common to all slums-, outsiders need the community to inform the process. The solid VES' $\mathrm{CBO}$ has so far been able to produce impressive results: no more does the settlement suffer from a lack of basic services, Lima's metro system has reached the area, and literacy and electrification rates are well above the Peruvian average (King \& Abbot, 2016). However, when it comes to who should take part in community participation the answer is not as obvious as 'everyone'. Inviting all community members to take part is unmanageable, so methods for fair, rotating representation must be designed from the onset. In order to create an effective representative system, learning about the community is paramount. In line with this, working through existing $\mathrm{CBO}$ s is essential. These actors have key contacts, networks and influence in the community that should not be undermined by the imposition of external organizers (Stein, 2001: 34). As it happens in VES, all initiatives are implemented through CUAVES to make the most of participation. Then, the CBO carries out the task of boosting community participation at large: it analyzes which who will perform which task best, and so it assigns (TECHO, 2015: 136). Moreover, one should remark the importance of preparing in-coming professionals in working with $\mathrm{CBO}$ s in a manner that favors development from below--i.e., to turn them into self-sustaining communities (Bartesaghi Koc, 2014: 5).

However, the organization capacity of VES does not exist in the majority of informal settlements, but it must be encouraged in order to create in the people a sense of ownership towards their habitat (Calderón Arcilla, 2008: 33). The Integral Development Plan for VES demonstrates that community participation alone does not suffice; it needs the support of a slum upgrading program to give structure to the transformation. What was achieved through the combination of a slum upgrading program and community participation in VES sets a precedent on how to go beyond the physical to create more integrated, emphatic societies. The upgrading of a community is difficultly achieved if the people concerned do not inform, take part, nor approve of the process.

\subsection{Access to credit, transparency and good governance: PRODEL (Nicaragua)}

During the 1990s, the Swedish International Development Agency (Sida) conceived a new generation of slum upgrading initiatives to reach the lowestincome quintiles, among which stands out the Local Development Program (PRODEL) in Nicaragua. This program was implemented in 1994 with a reach of six Nicaraguan cities. Due to its success, it is now a foundation, which extended its scope to reach thirteen municipalities. So far it has benefited more than 78,000 families. The PRODEL is based on the principle of self-help: it does not carry out any work, but provides assistance and support to settlers and authorities alike (Stein, 2001: 11-14). Through an innovative financial scheme, the PRODEL eventuated in sustainable access to credit, good governance and transparency. Its 
achievements give evidence of the magnitude that these three elements can make upon slum upgrading programs (Sida, 2005: 1-12).

The program's loan structure generated a revolving fund of the initial \$7 million invested by Sida: families receive a loan, use it to cover their needs, and then repay it by instalments to PRODEL (Sida, 2005: 1-12). In order to reach the often-overlooked lowest-income groups, the PRODEL establishes a selection criteria consonant with the socio-economic realities of such groups. In doing this, it acknowledges that the state and funding institutions do not have an obligation-or the capacity-to provide housing to all. Instead, what these actors are obliged to is guaranteeing that all families have access to market opportunities on a more equal footing (Ibid.: 159-160). Such rethinking of what funding should encompass ensues increased governability and transparency.

Even to this day, Latin America at large is affected by a clear governability deficit. This includes weak institutions, deficient mechanisms for citizen participation, clientelism, patronage, and corruption, to name a few (Irazábal, 2009: 27). In the context of post-revolutionary Nicaragua this was even more widespread: two decades of war and political polarization had left a country in an unstable and critical condition (Stein, 2001: 12). That is why the PRODEL had to pay special attention to governability through institutional development, technical assistance, and national reconciliation. In the context of slum upgrading, good governance is fundamental to attain effectiveness and efficiency. There is no better way to think of good governance than through outcomes. Due to a rigorous financial framework (i.e., strict loan system with a low rate of arrears) and the strong Sida supervision throughout the upgrading, the PRODEL achieved a scale of upgraded infrastructure nearly twice as much than originally planned. Furthermore, a common slum upgrading methodology was established for all majors and political parties, which ensured that slum upgrading continued unhindered by changes in political leadership. Institutions were strengthened through funding and capacity-training. (Ibid: 12-28).

The combination of a self-help loan system and of increased good governance yields enhanced transparency in slum upgrading mechanisms. Transparency is relevant because it ensures cost-effectiveness and heals the relationship between communities and authorities by building on trust. As it is the case of the PRODEL, loan application procedures must be transparent and fully understood by beneficiaries-to-be. Criteria for beneficiary selection should objective, and based on measurable, impersonal factors. The self-help, participatory approach applied throughout all upgrading stages enables communities to control and audit municipalities. For example, CBOs participate in the evaluation of the project, monitor the investment of funds, and take part in budget preparation. With municipalities better reporting to communities, national reconciliation and community cohesion are fostered. Furthering comprehension, transparency allows, on one side, for communities to really grasp the role of local authorities, their real limitations and financial resources; and, on the other, for authorities to listen, work with, and support slum residents (Stein, 1999: 22-31).

All things considered, the PRODEL transformed many slums in Nicaragua by providing a solid bureaucratic buttress. As exemplified by the Nicaraguan model, in order to trigger effective results, a slum upgrading program must ensure access to credit, propitiate good governance, and aim at transparency in all actions and at all levels (Stein, 1999: 32). Together with security of tenure, basic services, and 
community participation, these elements constitute the base of the pyramid: they make up the foundation for unleashing the vast potential of the urban poor.

\subsection{Cost recovery and budget control mechanisms: Self-Management Program (Mexico)}

The upgrading of slums in Tijuana pioneered an approach that delegates on communities for the management, execution and partial financing of projects. The Self-Management Slum Upgrading Program was implemented in 1990 at the municipal level of Tijuana. Its mandate encompasses slum and home upgrading, land regularization, basic services and infrastructure provision. The program, still ongoing, has become a key element of Tijuana's poverty reduction strategy and improved the quality of life of many-even though most achievements are only physical. It encouraged the city's squatter communities to actively and autonomously manage the upgrading project cycle. This generated very sustainable dynamics. Not only did thus Tijuanan slum dwellers become protagonists of their own development, but they also became well-versed in budget administration and in the real constraints of project-financing (Ruster \& Imparato, 2003: 397-400).

Budget control and cost recovery are essential elements to ensure the sustainability of the achieved upgrading. By applying measures to keep the project within budget, one ensures that the project does not stall for a 'sudden' lack of funding, and that cost recovery is more easily attained (Van Dijk et al., 2014: 209). Meanwhile, cost recovery overcomes paternalistic tendencies in slum upgrading, as well as it guarantees that informal settlements develop sustainably (Ruster \& Imparato, 2003: 9). In this sense, Tijuana's Self-Management Program operates at a very high level of cost-recovery: communities (through self-management committees) are informed and included at all stages of the upgrading program. Being informed entails that they are in the know of real costs and available funds at all times. For its part, being included-besides involving them in decisionmaking-requires communities to make a financial effort. In the case of Tijuana, for the Municipality to partially subsidize the project, slum residents need to contribute at least $30 \%$ of the project's total value. This ensures mainly four outcomes: First, costly solutions are avoided, and therefore the project is kept within budget. Second, the Government only subsidizes those works that communities really need/want. Third, communities develop an early appreciation of each project, which in turn enhances their readiness to maintain them in the long-term. And fourth, dwellers learn that development cannot be obtained for free but as a result of their own efforts, which are then correspondingly rewarded (Anguiano \& Ordoñez, 1994: 69-74). Moreover, Tijuanan slum dwellers further ensure cost-recovery of the program by conducting most upgrading works themselves (Ruster \& Imparato, 2003: 70).

The principle of cost recovery lies in the idea that a real cash flow is generated and that the investments for upgraded services/infrastructure can be paid back through returns (Van Dijk et al., 2014: 209). However, making the communities commit to full cost-recovery would be quixotic: slum dwellers operate in the informal sector in order to avoid such costs. This is why cost recovery mechanisms should be smart. Squatter communities need to learn the benefits of entering into formality and the advantages of contributing a share of total costs. One of the 
merits of slum improvement is that its completion, if done right, ensures cost recovery: comprehensively upgraded squatter areas will bring heightened economic profits both to the community itself and to the city (and country) at large. Tijuana's upgrading model shows that, when integrated and informed, slum dwellers are willing to pay for services, and that their inclusion in project financing turns slum upgrading more affordable and sustainable (Calderón Arcilla, 2008: 28). The fact that 77,000 lives have been improved through this program demonstrates the effectiveness and weight of cost recovery and budget control mechanisms in slum upgrading (Ruster \& Imparato, 2003: 397).

\subsection{Political will and social capital: Rosario Habitat Program (Argentina)}

The Rosario Habitat Program is particularly special due to its strong focus on the social dimension of upgrading; in particular, it is driven by political will and generates social capital among slum communities. Rosario is Argentina's third biggest city and, as such, it has received much of the immigration flows that cannot afford a porteño life. Before the program started in 2002, Rosario had the highest incidence of slums $(13 \%)$ in the country and poverty was there extreme. Still operating to this day, the Rosario Habitat Program has developed a comprehensive and integrational model that has qualitatively and consistently bettered the lives of 5,251 people. However, its scope has been limited, reaching only $1 / 10$ of Rosario's slum dwellers. The Habitat Program's success lies notwithstanding in its combination of physical and social slum upgrading initiatives and in the interaction and complementarity among these (Saborido, 2006: 57-68).

The Rosario Habitat Program gives evidence of the considerable bearing that political will has in slum upgrading. All the elements analyzed in foregoing and ensuing sections would stall in the absence of political will or in case of political unwillingness. In Rosario, the local government has been making constant efforts to update and upgrade its slum assessment policies. Indeed, one of its innovative lines is that local authorities show readiness to make self-critical assessments. As shown in the Rosario upgrading program, local authorities are the political entities with most potential to fully comprehend the realities of an area and the needs of its inhabitants. Therefore, although political will should emerge at all political levels, special emphasis should be put on local activity (TECHO, 2015: 136).

Among all the benefits yielded by strong political will, the Rosario Habitat Program epitomizes the meaningfulness of social capital. The connection between the two concepts is that both are based on trust. Applied to slum upgrading, social capital constitutes an anchor for sustainable development. Urban experts have acknowledged that the design and form of cities and buildings influence the way people interact and bond with each other; i.e., urbanism can promote community building and, therefore, give rise to social capital (Moobela et al., 2009: 257). The way urban design can facilitate and allow the growth of social capital is, for instance, by retaining people longer at public places, engaging them in continuous social interaction. Based on solid political will, the Rosario Habitat Program generates social capital through strengthened institutions, community participation at all stages, the creation of employment opportunities, education, and cultural activities. The combination of these initiatives triggers an approach to slum upgrading whose achievements are much more interweaved; ergo, more resilient, strong and autonomous. But, above all, Rosario has been efficient in 
generating social capital because it does not conceive the people and their involvement as a means but as the end itself.

One of the most palpable benefits of promoting social capital is that, it has been proven that in places where social capital is high its inhabitants tend to invest more time and efforts on the community on the perception that others will reciprocate. The pool of resources resulting from these actions represents a powerful instrument in slum upgrading. For example, it improves people's health and happiness, boosts economic development, sets safe neighborhoods, and betters the communities' relationships with the authorities (Moobela et al., 2009: 256-257). In this sense, Latin America has a comparative advantage: the region is profoundly oriented towards the family and the community, yet remaining an individualistic society. There, social ties and networks very often replace deficits in services and opportunities of different nature (Saracostti, 2007: 519). Thereby, by institutionalizing the promotion of social capital in slum upgrading practices, slum dwellers will acquire more confidence on the promoting institutions as well as on their own capacities.

The experience of the Rosario Habitat Program identifies a deep interrelation between the social, urban and economic dimensions of slum upgrading, whose stimulation it deems key. This model recognizes that generating social capital and political will, through civil society participation and the strengthening of their capacities, is an effective approach for attaining substantial development. Political will is a guarantor of sustainable and integral development; while social capital ensures that achievements become autonomous and stable.

\subsection{Sustainability and monitoring: Neighborhood Improvement Program (Bolivia)}

The slum situation in Bolivia is one of the most critical in the region, with $58 \%$ of Bolivian families living in informal housing (Habitat for Humanity, 2017). Up until the 1990s, the country's approach to the slum question had been both inadequate and neglectful. From then onwards, however, the central government implemented decentralization measures and more integrated strategies, which yielded better results in slum upgrading. Within this new trend, in 1998, the IDB and the Bolivian Government conjointly designed a new approach to upgrading: the PROVIVIENDA, a national program to improve Bolivia's housing policy. It was composed of four subprograms ${ }^{6}$, of which the Neighborhood Improvement Subprogram (known in Spanish as SMB) undertook slum upgrading works. Ending in 2008 , the SMB exemplifies achieved sustainability. Contributing to this, the program bore in mind the traditional and cultural diversity of the country at all times (Rivas, 2007: 4-5).

In recent years, slum upgrading programs in Latin America have made considerable progress as more integrated approaches are adopted. However, sustainability is still the main challenge. The region undertakes multiple initiatives for the improvement of slums, and it is commonplace that, when observed some years into completion, results are found to be in decay (Mitlin, 2002: 176). Thereby, the region at large needs to place more efforts in attaining sustainable slum

\footnotetext{
Página 299

6 The Demand Subsidies Subprogram, the Subsidy Program for Endemic Areas of Chagas Disease, the Natural Disasters Subsidies Subprogram, and the Neighborhood Improvement Subprogram (FOPEVI 2009: 34).
} 
upgrading. Otherwise, all work becomes futile. As it is the case of Bolivia's SMB, a program is sustainable when it generates permanent improvements and triggers a long-term development process (Ruster \& Imparato, 2003: 42). Planning in sustainability requires addressing five dimensions ${ }^{7}$. First, the conservation of physical benefits. Second, the training and motivation of the community to spark lasting social development. Third, the economic growth of the area, aiming for selfsufficiency. Fourth, the optimization of the program's funds. And fifth, the coalescence of all initiatives and works with the environment.

In terms of physical sustainability, the SMB teaches valuable lessons. For one thing, only once the community had convened and agreed on priorities did the works start. This ensured that the program only conducted initiatives needed by and adapted to the people. To illustrate, a significant share of the funds was invested in building community centers, which goes in line with Bolivia's community tradition. Also important for the sustainability of physical achievements, dwellers were taught how to maintain results. Involved in the construction stage, the community automatically developed maintenance skills. In line with this, slum upgrading must always aim for initiatives that the people will be able to preserve in the longer term: expensive or complex enterprises are therefore to be avoided (Rivas, 2007: 18-26). Although only achieved in some of the 26 cities intervened by the $\mathrm{SMB}^{8}$--due to insufficient funding-, upgrading programs must become part of local development plans in order to have a legal framework ensuring continuity (Calderón Arcilla, 2008: 28).

The strong component of the SMB, however, was social development. In conceiving the communities as social catalysts, training and motivating them for social progress, social sustainability was attained. This was realized by fostering community participation and by teaching the community about the effects and responsibilities entailed in them participating. Initiatives on sexual education and gender equality helped to combat stereotypes thwarting social development. Also, by building community centers and paving sidewalks, interaction among residents was enhanced and social capital promoted. This resulted in a solid network of social support (e.g., childcare, collective works, health centers, etc.) that fostered the continuity of the upgrading (Rivas, 2007: 21-22). Nevertheless, the key for attaining social sustainability was the combination of social development with the adequate technical support. Experts prepared communities in planning, execution, financing, monitoring and maintenance of slum upgrading, as well as in social and economic development. The program completed, all these strategies had created momentum for the communities to autonomously explore further ways to improve (Winchester, 2005: 17).

Regarding economic sustainability, it is imperative for slum upgrading to sustain the capacity of residents to draw on the market, both individually and collectively (Mitlin, 2002: 177). Program funds should not be merely spent; they should be invested. The SMB had several components illustrating this course of action. In particular, the Bolivian program encouraged handicrafts production as well as training on different areas (e.g., plumbing, gardening, electricity and construction). Interviews conducted by the national coordinator of the SMB, Sara

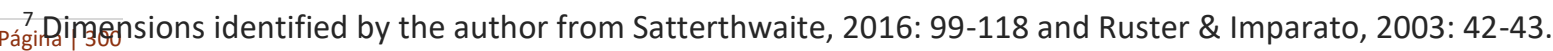

${ }^{8}$ Only the wealthiest municipalities, as La Paz, were able to integrate the program as a line of action of its municipal development plan.
} 
Rivas, indicate that many people could later access the labor market or earn extra income due to these acquired skills (Rivas, 2007: 27-53). In addition, the training that people received also strengthened their ability to voice their needs to the authorities. In conjunction with social sustainability, these economically sustainable actions also fostered local commerce initiatives and even tourism (Ibid.: 21-22).

For its part, a financially sustainable program is one that creates within itself the conditions to secure and optimize the available funds - without requiring extra capital. Achievements need to be affordable both to communities and to the local government/development agency providing funds (Mitlin, 2002: 175). The SMB attained this through a transparent public tendering system for selecting the beneficiary municipalities. Since joining in the program was voluntary, the municipalities that decided to take part were thorough observants of the requirement of contributing $30-40 \%$ of the program's value. Complementing this, the training the community received was also critical for financial sustainability. First, because the labor they contributed considerably reduced costs. And second, because such training taught them to require the upgrading of elements that were of utmost necessity, which, in turn, were maintained more readily (Winchester, 2005: 17).

A pioneering aspect of the SMB was its disposition to protect the environment. Given the climatologic conditions in some Bolivian cities, the number of trees and green areas is there very limited. In addition, urbanization very often deprives city areas of vegetation. Thus, the SMB conducted a study to see which trees thrived best in each of the national climates, and carried out reforestation and tree planting initiatives. These actions also addressed risks of erosion and landslide in informal settlements. Such projects increased the environmental sustainability of the cities at large, and improved the quality of life in and the aesthetics of the areas intervened (Rivas, 2007: 14). At present, communities feel proud about their neighborhoods and more esteemed by their governments. Workshops on hygiene, public spirit and environmental protection were also conducted (Ibid.: 27-53).

In slum upgrading terms, environmental sustainability refers to the ability of an ecosystem to remain undamaged after the improvement cycle is completed (Mitlin, 2002: 174). Latin America, as most developing regions, faces this task from a position comparative disadvantage. Rapid urbanization has led to lacking infrastructure, informal settlements in vulnerable areas, resource depletion, pollution, inadequate management of air and solid waste, deficient mobility policies, and human habits that aggravate these challenges (Ezquiaga, 2015: 10). Such inefficient subsystems hinder the capacity of the entire region to become sustainable, a situation that will only become more harmful. It is thereby imperative that Latin America conceives far-reaching slum upgrading programs that strive for environmental sustainability. This will turn urban planners and communities into a sort of 'doctors of the city' (Mostafavi \& Doherty, 2016: 10).

Having discussed the five dimensions of sustainable slum upgrading, it is essential that programs also involve mechanisms for their maintenance and monitoring. Again, the SMB sets a good example on how to do so. In the Bolivian case, maintenance was planned between both the community and planner designers before implementation began. This enabled both parties to prepare for future responsibilities and learn the best way to maintain elements they had seen throughout construction. Also during its planning stage, the SMB designed its 
future methods for monitoring. This anticipation allowed to better record information, which improved monitoring results and the extracting of lessons during and after slum upgrading (Brakarz et al., 2002: 115-121).

All things considered, sustainability is the finest indicator of slum upgrading success. The accomplishments of the SMB show that sustainability-in all its dimensions-has enormous impact on the larger city's competitiveness and development, as more investment is attracted, more productive jobs are created, and more cohesion is generated among citizens. Monitoring and maintenance strategies are the medium to ensure lasting achievements. This model, set by the $\mathrm{SMB}$, was legitimized by the further development that took place in Bolivian cities after the program's completion.

\subsection{Strong intermediary structure: Popular Habitat Program (Costa Rica)}

During the 1980s, Costa Rica suffered a serious economic crisis that exacerbated the country's soaring housing deficit and elevated the number of informal settlements. Up until that period, the slum problem had been only addressed through subsidized resettlement. The result was that when squatters were moved into subsidized housing areas, new families reoccupied the slums almost straightaway. In addition, national housing subsidies never reached the poorest. Funds were almost often hijacked by middle and lower-middle classes while lowest-income groups were left excluded. Thus, in 1987, Costa Rican authorities acted to reverse these vicious patterns with the setting-up of the Foundation for the Promotion of Housing (FUPROVI). Given the dire economic situation, the country received a development aid package ( $\$ 14$ million) from Sida-to be managed by FUPROVI. With these funds, the Government and foundation set in motion the Popular Habitat Program to address the slum question. This program pioneered the use of an intermediary structure in slum upgrading: FUPROVI acted as a mediator between the government and the people, enhancing transparency and efficiency, and yielding stupenduous results (Ruster \& Imparato, 2003: 65-69; Sida, 1997: 216-231).

Plan formulation and implementation is usually very politicized in Latin America (i.e., clientelism, populism and patronage). The cities in the region are however making progress in good governance. In parallel, many slum upgrading programs are including a component of institutional strengthening (Irazábal, 2009: 27). By setting up an intermediary structure for slum upgrading actions, unnecessary bureaucratic hurdles are avoided and the results magnified. In most slum upgrading scenarios, there is a wide range of stakeholders: residents, public authorities, public and private companies, landowners, donors, and NGOs. All of these require a non-partisan entity that brings them all together, sets strategic partnerships among them, and allows each to give their best; all while protecting the interests of the whole and of each party (Ruster \& Imparato, 2003: 8).

In the case of the Popular Habitat Program, the FUPROVI constituted an independent structure that eased communications between all stakeholders. After thirty years, the program is still in place. So far, it has increased the flexibility and efficiency, strengthened community organization and participation, built the communities' capacities, and helped improve the lives of 80,000 Costa Ricans. Although intermediary structures can take many shapes, the way the FUPROVI 
works is by enabling slum dwellers to access the national subsidy system. First, FUPROVI loans the families money from the Swedish aid package. Then, once the families have obtained the national housing subsidy from the government, they pay FUPROVI back. In this manner, squatters are integrated into the national financial system, and FUPROVI keeps a rotating, revolving fund, which allows it to continuously help more families. The Popular Habitat Program also makes special allocations to institutional development, technical support and capacity building, in order to guarantee sustainability and future self-sufficiency (Ruster \& Imparato, 2003: 381-385).

The FUPROVI model illustrates that having an independent institutional setup exclusively dedicated to coordinate and manage slum upgrading programs bears more fruitful results. Intermediaries permit to create a technical body of knowhow tailored to the country or area where it operates. Involved from the start, an intermediary structure can develop an ordained information-gathering system, which serves for monitoring present endeavors as well as for extracting lessons for improved performance. Such systematized agent is to be composed of technical experts that enhance all stages of slum upgrading, without incurring in extra costs: their salaries come out of the revolving fund (Ruster \& Imparato, 2003: 65-69). Additionally, the Costa Rican experience shows that intermediary structures are critical when community participation and organization are weak or insufficient, as they possess the necessary expertise to trigger community action (Irazábal, 2009: 98).

The FUPROVI model gave place to institutional innovation, transparency and efficiency. The continuity generated by its revolving fund yielded autonomy from partisan politics. This was all the more beneficial for the communities, who could enjoy constant assistance in improving their homes and developing their communities. Moreover, the well-functioning foundation has produced clear standardized procedures and refined managerial and information systems (Sida, 1997: 218). In its thirty-year trajectory, both the FUPROVI and Popular Habitat Program have enriched Costa Rica's results in slum upgrading, demonstrating the relevance of strong intermediary structures.

\subsection{Integral and multidisciplinary approach: PUI Nororiental Initiative (Colombia)}

The slum question in Colombia is one of the most alarming in the region. Its long history of internal armed conflict generated one of the highest global rates of internally displaced people (Magalhães, 2016: 63). This situation critically affected the urbanization process of the country. Also, the drug cartel's demand for rural land during the 1980s gave place to additional rural-urban migration. The overall effect of such circumstances has been burgeoning numbers of informal settlements across the country. Against this background, several Colombian cities started to make progress in addressing the situation, among which Medellin stands out for its revolutionary development capacity. The present Medellin highly differs from the dangerous, narcoterrorism-affected, poverty-stricken city of the 1990s (Ibid: 67). This transformation was due both to the PRIMED (Integral Program of Improvement of Subnormal Districts) (1993-2004) and to the more recent Integrated Urban Program (PUI) (2004-2011). The PUI could only take place after the springboard of the PRIMED, which addressed basic needs, infrastructure 
deficits, slum upgrading, land tenure regularization, and the relocation of families occupying areas of high geographic risk. This set a solid base for the PUI to enter the scene. This program is based on the premise that integral, interconnected, emblematic programs within informal settlements, connected with social undertakings, will have a tremendous impact on the lives of the poor (Ibid: 77-82).

The full PUI intervened in each of the city's slum pockets by applying this integral, multi-disciplinary approach. It formulated programs that were tailored to the potential and challenges of each particular slum area. The PUI Nororiental Initiative--our focus of study-was the pilot project of the PUI model. The nororiental zone-linked to the Medellin cartel and paramilitary groups-was selected because of its alarmingly low HDI levels and high homicide rates (Calderón Arcilla, 2008: 8). The whole program epitomizes an integral and multidisciplinary intervention: it consists of strategically interconnected projects that coalesce in transforming the many dimensions of slums. Composed of physical, social, institutional, cultural, and psychological interventions, the PUI is based on the concept of 'social urbanism' (Magalhães, 2016: 77).

Due to its comprehensive character, initiatives as the PUI are the best first steps into the notion of 'placemaking'. Comprehension of the particularities of the place and acknowledgment of the multi-dimensionality of resident's needs unveils a whole new realm for slum upgrading. For the slum problem is not solely made of physical components, but also of social, institutional, cultural, and psychological elements. The expectations created by the life in the slum determine the behavior of its residents. As slums are not urbanistically conceived for community livingand "places construct people" (Holloway \& Hubbard, 2001: 7)--, the hopes and behaviors of dwellers are merely a by-product of the places they live in. This contributes negatively to the vicious cycle in which they are trapped. As economists Max-Neef, Elizalde and Hopenhayn would say, the life in the slum is a clear example of a self-fulfilling prophecy (Max-Neef et al., 2010: 19). Therefore, the only way to tackle such conundrum is by means of an integral and multidisciplinary approach.

In order to enable the combination of slum upgrading and placemaking do its magic, a program must, first and foremost, avoid overregulating the organic life that blossomed in the absence of public support (Risom \& Madriz, 2018). The process of intervening a slum area must identify strengths and weaknesses, and work along the place's potential. To that end, planners need a proper understanding of the characteristics of slums and their inhabitants. This is best accomplished by integrating and respecting the community at all stages; not by merely consulting decisions with them but by planning everything with them. The PUI attained this scenario through the so-called 'problem identification', 'prioritization' and 'imagination' workshops, which actively involved community members throughout the program cycle (Magalhães, 2016: 81). Since formal cities already cover all anthropological needs and face no hurdle, the PUI planned for the integration of the slums into the adjacent formal grid (e.g., through improved public transport networks, cultural initiatives and increased institutional presence). This brought more equal opportunities to all citizens (Calderón Arcilla, 2008: 56). Hence, informal mechanisms were not substituted by formal structures, but rather were complemented by them. Such approach facilitates a multidisciplinary scheme, enabling all interventions to be buttressed by broader formal structures (e.g., public and private companies) (Ibid.: 30). Additionally, all 
of the PUI's components forged more integrated social networks that in turn fostered community building, development and sustainability (Ibid.: 56 ).

A major innovation of the PUI was its breaking of the exclusion cycle that ensnares underprivileged neighborhoods. By means of an integral and multidisciplinary approach it tackled all deficits at once, attaining robust achievements that bolstered one another. To illustrate, the physical interventions of the program significantly increased the quality of life in Medellin's nororiental zone. Projects such as home upgrading, health clinics construction or piping systems positively affected the physical health of slum dwellers. For its part, social, cultural and psychological interventions like local economic development, music or dance promotion, and more colorful and qualitative infrastructure had a valuable impact on the mental health of community members. Literacy rates, education and culture were heightened by pedagogic workshops and the construction of libraries (Calderón Arcilla, 2008: 105-108). The multidisciplinary nature of the program permitted to enhance community participation. Solid participation originated more positive relationships between the community and the authorities, rendering a more humanized process. Moreover, safety and security improved as communities integrally developed in owning their own progress. In fact, PUI's new facilities are characterized by cleanliness and absence of vandalism. Last, such comprehensive transformation attracted private and international investment in the area (Magalhães, 2016: 82).

As has been noted, slum upgrading should be integral and encompass various disciplines. The PUI Nororiental Initiative illustrates that only through investment in all dimensions can slum upgrading overcome all shortcomings and tackle the root causes of poverty. Another important accomplishment of an integral, multidisciplinary approach is that it plants the seeds for placemaking to sprout.

\subsection{Bridging the gap between a development project \& social progress: PROUME (Guatemala)}

The upgrading of El Mezquital, Guatemala constitutes a success story in itself. It occurred in the framework of the Guatemalan Civil War (1960-1996). Carried out by the PROUME (Program for the Urbanization of El Mezquital) (1993-1997), upgrading works started in a penurious panorama. There were virtually no basic services or infrastructure in this area of Guatemala City. However, the high levels of community organization caught the eye of a WB mission. For this reason, El Mezquital became the recipient of a \$14-million aid development package from the WB, to which UNICEF also contributed (Ruster \& Imparato, 2003: 83-85). What makes this program special was its bridging of the gap between a development project and social progress. Twenty years after the completion of the program, the community has internalized a pro-development attitude. To this day, they continue their own development despite the many hurdles they have found in the road (Drummond, 2005: 28).

A development project that does not turn into social progress ignores the human dimension of it all, and, as a result, does not result in placemaking. Drawing inspiration from Ruster \& Imparato's "bridging of the gap between a development project and a social process" (Ruster \& Imparato, 2003: 95), we consider that reaching social progress involves a full penetration of the program into the 
community. That is to say, that the program interacts at all stages and from all its components with the people and with their complex agglomeration of culture, internal dynamics, demands, vested interests, expectations, and perspectives about the upgrading. Therefore, essential in this bridging are the community participation and community building elements.

The attention given to building this bridge is grounded on the idea that slum dwellers are often their own main opponents. According to the concept of 'placemaking', the areas people live in shape their identities. Hence, the notion of bridging the gap entails a strong psychological component. As did the PROUME, slum upgrading programs must encourage slum residents about their inherent value and transformation potential. In order to properly achieve this, the PROUME identified the social architecture of the community and worked along residents by filling in the gaps. In addition, the program diligently removed obstacles for future social progress. This aspect is very important in bridging the gap, since habits and stereotypes can hamper the autonomy acquired through physical development. In this line, the PROUME attached great importance to fighting male chauvinistic stereotypes and developing of family ties. It also endeavored to make progress in sexual education, as the country suffers from big rates of HIV/AIDS. Moreover, the program gave a central role to women empowerment: it promoted female leadership, provided legal assistance to combat gender-based violence, and constructed a center for women's needs (Drummond, 2005: 27).

All things considered, the PROUME was successful in creating the appropriate conditions for social and autonomous progress. The bridging of the gap cannot be separated from placemaking. The gap bridged, communities change their attitudes about the future and acquire the skills to fulfill their aspirations. All the elements analyzed in previous sections are essential to achieve this. Nonetheless, for placemaking and slum upgrading to reach their full potential an additional aspect is needed-equity, esteem and inclusion--which will be discussed in the following section.

\subsection{Equity, esteem and inclusion: Library Parks, Schools and Metrocable System (Colombia)}

The tip of Meléndez's Pyramid is 'Equity, Esteem and Inclusion'. These last elements were thoroughly inspired by Medellin's amalgam of Library Parks, educational institutions and Metrocable $^{9}$ system (2001-ongoing). The three projects are part of a strategy within the broader framework of the PUI, which conceives urbanism as an instrument for social inclusion. Within this context, the three projects carried out qualitative and appealing works that linked the upgraded-slums with the broader city. The benefits of such initiatives were precisely the enhancing of equity, esteem and inclusion among Medellin's slum residents (Esteves, 2012: 157-166). Medellin's Secretary of Civic Culture and Social Development, Jorge Melguizo, delineated the rationale of these projects in two sentences: "the public sphere as a guarantee, as a possibility of inclusion and equity", and "the best spaces, the best possibilities for those who had nothing ${ }^{10}$." (Melguizo, 2011).

\footnotetext{
Página 306

${ }^{9}$ Name of the cable car system of Medellin.

${ }^{10}$ Translation by the authors, original at Melguizo, 2011.
} 
As of 2018, the three projects together have given place to 9 Library Parks, 10 educational institutions, and 3 Metrocable lines (with 2 more lines under construction). The Library Parks and educational institutions are located in the poorest areas of the metropolis, while the Metrocable system links these zones and their new facilities to the city center, and vice versa. Such network creates a sense of belonging among the poorest quintiles: it gives them more equitable opportunities, fights social stigma, and enhances social cohesion throughout the city. Slum upgrading that fails to provide public spaces, opportunities for culture and education, and adequate public transportation, can yield breeding grounds for health and social problems (Magalhães, 2016: 7). When the bridging of the gap and the benefits of placemaking are ignored, development cannot be sustainable. Solving the slum question necessitates the transformation of the political culture, which will hardly be attained if interventions are only focused on infrastructure and on the poorest urban areas. As does the Medellin strategy, slum upgrading must target culture, education and public transport citywide, to realize society's mutual comprehension (Ibid.: 37).

Distressingly, most slum upgrading practices and housing policies in Latin America have not yet internalized the relevance of qualitative culture, education and public transportation. Thus, they fail to consider a vital socio-spatial dimension. Instead, a quantitative vision predominates in the region's urban planning, resulting in a deepening segregation and denigration of the urban poor (Ibid.: 7). To reverse this condition, slum upgrading programs must include elements that foster equity, esteem and inclusion. Hence, we propose that culture, education, and adequate public transport systems as excellent means to accomplish such endeavor.

Public spaces are the ideal ground for the 'right to the city' to fully realize itself. They are sites of coexistence and sharing; channels for expressing culture and exercising citizenship. Medellin's 9 Library Parks have produced new axles of growth within the city's poorest areas (Esteves, 2012: 163). They conform a sociocultural development strategy: public spaces generate interaction on a more equal footing, unlocking prejudice and social stigma. These sites-very esthetic in character-have become touristic attractions, welcoming 'formal' citizens and foreigners. This, in turn, has broken the cycle of fear and insecurity prevalent in these areas, both inwardly and outwardly. Insecurity and violence were combated through coexistence, which is precisely what public spaces promote (Melguizo, 2011). Thus, the Library Parks have conferred a new image to previously stigmatized communities by dignifying them. Moreover, the sense of pride generated by such places fosters social capital generation (Vilar \& Cartes, 2016: 64). Ultimately, public spaces make urban life easier and transcend into the emotional of people to generate feelings of equity, esteem and inclusion.

For their part, the 10 educational institutions benefited 7,916 students, contributing to the broader aim of achieving public education for all of Medellin's children and adolescents. Teaching in education and culture from an early age is proven to empower communities more effectively and to be vital for social capital (Vilar \& Cartes, 2016: 62). In fact, since Medellin has given priority to education and culture (2004), statistics show that the city has experienced a considerable increase in HDI levels (Herrera Marín, 2013: 103-109). One of the most staggering results has been the manner in which the communities have welcomed this approach. For example, in 2007 the neighborhood of Aranjuez dedicated 65\% of 
its participative budget funds to both culture and education. This shows that, when given the opportunity, people are interested in developing cultural and educational activities, seeing those as an effective way to break away from poverty (Cátedra Medellín Barcelona, 2012: 179-185).

Nonetheless, education and cultural provision must not merely exist but also be accessible. In most cases, slums and poor neighborhoods are located either far from the city center or on the steep hillsides of the city, as it is the case of Medellin. The PUI's introduction of qualitative public transportation in the city's poorest areas was a quest to dignify people's time. Before the arrival of the Metrocable, residents of these areas took an average of 1.5-2 hours to reach the city center. Before 2004, public transportation was faulty, of low frequency and even dangerous. Taxi services (as police services did) avoided these neighborhoods. The remaining option was descending and ascending the hillsides by foot. As a result, economic and labor opportunities, social interaction with other city areas, and access to culture and education were limited to the neighborhood of residence (Heinrichs \& Bernet, 2014: 55-67). Thus, these aerial cable cars (Metrocable) do not only link educational and cultural sites located in the poorest neighborhoods; they also connect the residents of these areas with the larger city and with all the opportunities that so entails. The outcome is a more equitable city.

The cable car system is an excellent solution for attaining real development in slum areas due to its multiple benefits. Other Latin American cities as La Paz or Caracas have also connected informal settlements to the formal city through cable cars. First and foremost, this mode of public transport is a low-emissions one, requiring less electrical power. Their aerial position means that they can be easily integrated into the transportation cityscape, without competing with traffic. They entail no-wait service and are accessible to passengers with impaired mobility (McConville, 2010). Additionally, these mechanisms are relatively cheap and can even be free in the long term due to trip fares. For instance, the Municipality of Medellin predicts full cost-recovery in 10-15 years into its inauguration. More than that, Medellin's Metrocable system has become a tourist attraction, which in turn has increased commerce opportunities in informal settlements and heihgtened their residents' feelings of inclusion and esteem vis-à-vis the city (Heinrichs \& Bernet, 2014: 66).

In spite of their recognized benefits, public spaces, education, culture and public transportation are however almost always disregarded by slum upgrading practices. This neglect of emotional components-as are equity, esteem and inclusion-results in an incomplete addressing of the slum problem. The previous section described the bridging of the gap for attaining social progress, and referred to the need to add psychological elements to slum upgrading. This section completes an integral approach to slum upgrading by stressing the indispensability of conceiving slum upgrading schemes that also reach the emotional. Demonstrated by Medellin's Library Parks, educational institutions, and cablecar system, the combination of slum upgrading and placemaking has the power to target physical, economic, social, political, cultural, psychological and emotional human dimensions. Aiming for less would not solve any problem but only make a temporary fix. 


\section{CONCLUSION}

On the whole, slum upgrading and placemaking are the answer to many of the urban and human challenges confronting Latin America's present society. With bourgeoning rates of urbanization and $23.5 \%$ of its population living in informal settlements (UN Data, 2014), the region requires an integral transformation of its urban dynamics. The widespread presence of slums signals the malfunctioning of the present system, for it is indisputable that life in the slum violates human dignity. Also, slums pointlessly limit human potential in reaching beyond the present and vicious state of affairs. Striving for a permanent fix to the slum question entails addressing its root causes and fulfilling present deficits. In doing this, Latin America should aim for a policy that not only upgrades but that includes placemaking in its true sense. Slum upgrading practices must target physical, economic, social, political, cultural, psychological and emotional human dimensions (Max-Neef et al., 2010: 36). Taking all these aspects into account, the Melendez's Pyramid on Slum Upgrading advances a set of indispensable elements for Latin American programs to always include. The Pyramid draws from the premise that, until squatters' basic human needs are satisfied, human development will not be whole nor durable.

The matching of each pyramid bloc with a real slum upgrading program gives testimony of each element's actual impact and of the feasibility of its realization. The most valuable contribution of our Pyramid is its proposal for a change of urban rhetoric. Cities, as history, have been erected by winners, leaving so many in exclusion. The future of slum upgrading must thus encompass a system that places slum residents at the core. This is the only way to give birth to inclusive cities: when all intersecting factors that affect how we relate to space (i.e., race, ethnicity, social status, socioeconomic background, and gender) become aligned. Nonetheless, the biggest hindrance to this change of rhetoric is the lack of resource redistribution. By means of our Pyramid, we have tried to elucidate that cities' potential is nowadays insufficiently tapped. Therefore, the tension between the formal and the informal city-which are inseparable according to economic logic-must be put to good use through an integral slum upgrading. However, carrying this out runs into the problem of vested powerful interests: implementing such initiatives has thus remained elusive, not realizing how much is to gain from a change of approach.

Latin America's slum upgrading has been caught in a vicious cycle: most programs consist of merely physical, social or economic interventions. This generates little and unsustainable results, progress in one dimension undermined by the neglect of all others. As a result, donors become insecure and fatigued, which has led to funding wrought. Not seeing consistent and ongoing results, investment in slum upgrading has considerably decreased (UN-Habitat, 2016: 13, 106). By the same token, communities have lost hope on development, after decades of receiving no sustainable solutions. Future Latin American cities need strong housing policies and political will to redesign existing space, and thus become more equitable. And slum upgrading practices need to take into account the indispensable elements analyzed in this article. However, the region's cities face a bleak future unless political and economic forces become forthcoming. No matter how much slum upgrading adapts to the workings of the market, housing is and will remain a profitable market product. 
Then, the best deal to aim for is a renewal of the social contract. This can be perfectly achieved by means of slum upgrading, whose benefits reach deeply beyond slum limits. Here is where placemaking acquires real importancebecause, "as people construct places, places construct people" (Holloway \& Hubbard, 2001: 7). Squatter settlements are one of the most visual outcomes of the wrongs of present economic, political and social systems. Since informal housing is the result of multi-dimensional marginalization, undertaking slum upgrading will restore many of the ills of present systems. For the home is the locus for all development: the way architecture and urbanism work-both at the home, neighborhood, and city levels-influences people's lives to the deepest intimate degree. Thus, our most relevant recommendation is for Latin American cities to renew the 'right to the city', for the informal to be rethought, and for practices of integral slum upgrading and placemaking-as described in the present article-to be carried out throughout the region's peri-urbanity. 


\section{Melhoria e organização de favelas: melhorando assentamentos informais e criando lugares}

\section{RESUMO}

Desde a criação do UN-Habitat em 1978, as agendas de desenvolvimento refletiram uma crescente atenção global às cidades e questões urbanas. Devido ao rápido crescimento das taxas de urbanização em todo o mundo, os desafios urbanos - e principalmente os assentamentos informais - dificultam perigosamente o desenvolvimento humano. Apesar do reconhecimento internacional, as formas convencionais de lidar com assentamentos informais não alcançam resultados sólidos. No entanto, os fatos mostram que a América Latina se tornou um marco global em termos de desenvolvimento urbano abrangente e inclusivo. Os poucos programas abrangentes de melhoria de assentamentos informais embora significativos - na região testemunham isso. Com isso, vemos o potencial da região para liderar a consecução de um futuro mais próspero na melhoria dos assentamentos informais e, portanto, no campo do desenvolvimento humano. Para esse fim, foram escolhidos dez programas de melhoria latino-americanos para ilustrar a metodologia proposta para obter resultados mais completos e sustentáveis nas práticas de melhoria de bairros informais.

PALAVRAS-CHAVE: desenvolvimento urbano, desenvolvimento humano, América Latina, melhoria de assentamentos informais, planejamento urbano, criação de lugares. 


\section{BIBLIOGRAPHY}

Álvarez Rivadulla, M. J. (2014, September). Asentamientos irregulares y política en perspectiva histórica y comparada. Seminar "Programas Mejoramiento de Barrios en Uruguay, MVOTMA".

Anguiano, M. E., \& Ordoñez Barba, G. M. (1994). Pronasol en Baja California: negociación política y eficacia operativa. El Cotidiano, 62. p.69-74.

Arimah, B. C. (2010). The face of urban poverty. Explaining the prevalence of slums in developing countries (Working Paper $N^{\circ}$ 2010/30 prepared for UNUWIDER). Helsinki, Finland: UN University, World Institute for Development Economic Research.

Balbim, R. (Ed.) (2016). The Geopolitics of Cities: Old Challenges, New Issues. ISBN: 978-85-7811-289-9. Brasilia, Brazil: Federal Government of Brazil, IPEA. p.171-192. In-print.

Bartesaghi Koc, C. (2014) Squatter Settlements As Social Catalysts Towards A Sustainable Urban Development: A Positive Look At the Case of Villa El Salvador, Lima-Peru. 11th Symposium of International Urban Planning and Environment Association (UPE 11). La Plata, Argentina.

Brakarz, J., Rojas, E., \& Greene, M. (2002) Ciudades para todos: La experiencia reciente en programas de mejoramiento de barrios Washington, DC: IDB. p. 115122.

Calderón Arcilla, C. A. (2008). Learning from Slum Upgrading and Participation: A Case Study of Participatory Slum Upgrading in the Emergence of New Governance in the City of Medellín-Colombia (Master's thesis, Kungliga Tekniska Högskolan, KTH Stockholm).

Carvalho, R. (2013, September). Slums and cities in Brazil: comparison for Belo Horizonte and Rio de Janeiro. Seminar International Population Conference, XVII IUSSP, Busan, South Korea.

Cátedra Medellín Barcelona (2012). Construcción del modelo cultural: Entrevista con Jorge Melguizo.

Esping-Andersen, G. (1990). The Three Worlds of Welfare Capitalism. Boston, MA: Princeton University Press. 
Esteves, M. H. (2012). Shaping New Urban Environments in Latin America: The Case of Medellin, Colombia. Humanities and Social Sciences Review, 01(02), 157166.

Ezquiaga Arquitectura, Sociedad y Territorio S.L. (2015). The Experience of Latin America and the Caribbean in Urbanization. (Discussion Paper № IDB-DP-395). Washington D.C.: IDB.

Fernandes, E. (2007). Constructing the 'Right to the City' in Brazil. Social \& Legal Studies, 16(2), 201-219.

Fernandes, E. \& Pereira, H. D. (2010). Legalização das favelas: Qual é o problema de Belo Horizonte? Planejamento e Políticas Públicas, 34. p.171-199.

Habitat for Humanity (2017). Housing Poverty in Bolivia.

Hacker, K. P., Seto, K. C., Costa, F., Corburn, J., Reis, M. G., Ko, A., \& Diuk-Wasser, M. A. (2013). Urban Slum Structure: Integrating Socioeconomic and Land Cover Data to Model Slum Evolution in Salvador, Brazil. International Journal of Health Geographics, 12(45). p.1-12.

Harvey, D. (1973). Social Justice and the City. Baltimore, MD: John Hopkins University Press.

Heinrichs, D. \& Bernet, J. S. (2014). Public Transport and Accessibility in Informal Settlements: Aerial Cable Cars in Medellín, Colombia. Transportation Research Procedia, 4(2014) p.55-67.

Hernández, F., Kellet, P., \& Allen, L. K. (Eds.) (2010). Rethinking the Informal City: Critical Perspectives from Latin America. New York, NY: Berghahn Books. p.1-19. In-print.

Holloway, L., \& Hubbard, P. (2001). People and place: The extraordinary geographies of everyday life. Harlow: Pearson Education. p.1-81.

Irazábal, C. (2009) Revisiting Urban Planning in Latin America and the Caribbean: Global Report on Human Settlements 2009 for UN Habitat (Report prepared for UN-Habitat Global Report on Human Settlements) New York, NY: University of Columbia. 
Lefebvre, H. (1996). Writings on Cities. Hoboken, NY: Blackwell Publishing. p.146159.

Magalhães, F. (Ed.) (2016). Slum Upgrading and Housing in Latin America (No. IDB-CP-45). Washington D.C.: IDB.

Max-Neef, M., Elizalde, A., \& Hopenhayn, M. (2010). Desarrollo a escala humana. Opciones para el futuro. Madrid: Biblioteca $\mathrm{CF}+\mathrm{S}$.

McConville, M. (2010, April 7). Up, Up and Away in a Cable Car. The City Fix Magazine.

Melguizo, J. [TEDx Talks] (2011, September 5). Medellín, la ciudad creativa: Jorge Melguizo at TEDxBuenosAires [Video File].

Mitlin, D. (2002). Sustaining markets or sustaining poverty reduction? Environment \& Urbanization, 14(1) p.173-177.

Moobela, C., Price, A. D. F., Mathur, V. N., \& Paranagamage, P. (2009). Investigating the Physical Determinants of Social Capital and their Implications for Sustainable Urban Development. The International Journal of Environmental, Cultural, Economic \& Social Sustainability, 5(2).

Mostafavi, M. \& Doherty, G. (2016). Ecological Urbanism in Latin America. Revista Brasileira de Gestão Urbana (Brazilian Journal of Urban Management), 8(1). p.711.

Risom, J. \& Madriz, M. (2018, January 1). Embracing the Paradox of Planning for Informality. Next City Magazine.

Rivas, S. (2007). Subprograma Mejoramiento de Barrios en Bolivia. Lecciones aprendidas de proyectos integrales: componentes tangibles e intangibles (Cuaderno de Análisis No 16, Programa de Capacitación para el Mejoramiento Socio Habitacional [PROMESHA] and Housing Development \& Management [HDM]). Stockholdm, Sweden: Lund University. p-1-53.

Ruster, J., \& Imparato, I. (2003). Slum Upgrading and Participation: Lessons from Latin America. Washington D.C.: World Bank.

Saborido, M. (2006). Experiencias emblemáticas para la superación de la pobreza 
Saracostti, M. (2007) Social capital as a strategy to overcome poverty in Latin America. An Overview. International Social Work, 50(4) p.515-527.

Schneekloth, L., \& Shibley, R. (1995). Placemaking: The Art and Practice Of Building Communities. New York: Wiley.

Sida. (1997). New models for aid agencies seeking to improve housing for lowincome groups: Sida's initiatives in Costa Rica, Chile and Nicaragua. Environment and Urbanization, 9(2). p.213-232.

Sida. (2005). Los programas apoyados por Asdi en Centroamérica: Vivienda y desarrollo local (Report by Sida). Stokholm, Sweden: Sida. p. 1-12.

Stein, A. (1999). Participation and sustainability in social projects: the experience of the Local Development Programme (PRODEL) in Nicaragua (Report prepared for Sida).

Stein, A. (2001). Participation and sustainability in social projects: the experience of the PRODEL in Nicaragua. Environment and Urbanization, 13(1). p.11-36.

TECHO. (2015). Censo de asentamientos informales. Guatemala. Santiago de Chile, Chile: TECHO.

UN Data (2014). Proportion of urban population living in slums.

UN-Habitat. (2016). Slum Almanac 2015/2016. Tracking Improvement in the Lives of Slum Dwellers. Nairobi, Kenya: UNON Publishing Services Section.

Van Dijk, M. P., Etajak, S., Mwalwega, B. \& Ssempebwa, J. (2014). Financing sanitation and cost recovery in the slums of Dar es Salaam and Kampala. Habitat International, 43. p.206-213.

Vilar, K., \& Cartes. I. (2016) Urban design and social capital in slums. Case study: Moravia's neighborhood, Medellin, 2004-2014. Procedia-Social and Behavioral Sciences, 216. p.56- 67.

Winchester, L. (2005). Sustainable human settlements development in Latin America and the Caribbean (CEPAL - Medio ambiente y desarrollo No. 99). Santiago de Chile, Chile: CEPAL. 
World Bank. (2012). Cities Alliance for Cities Without Slums: Action Plan for Moving Slum Upgrading to Scale (Working Paper № 80948). Washington D.C.: World Bank.

Wright, F. L. (1939). An Organic Architecture: The Architecture of Democracy. London: Lund Humphries.

Recebido: 10 fev. 2020

Aprovado: 08 abr. 2020

DOI: $10.3895 /$ rbpd.v9n2.8906

Como citar: FUENTES, N. M.; PIRZKALL, H. C. P. Slum upgrading and placemaking: improving informal settlements and creating places. R. bras. Planej. Desenv. Curitiba, v. 9, n. 2, p. 285-316, mai./ago. 2020 Disponível em: <https://periodicos.utfpr.edu.br/rbpd>. Acesso em: XXX.

Correspondência:

Heike Clara Pintor Pirzkall

Calle de Alberto Aguilera, 23, 28015 Madrid, Espanha

Direito autoral: Este artigo está licenciado sob os termos da Licença CreativeCommons-Atribuição 4.0 Internacional. 